\title{
The Silence of the Wolves, Or, Why It Took the Holy Inquisition Seventy-Three Years to Ban Copernicanism ${ }^{1}$
}

\author{
Gereon Wolters
}

\begin{abstract}
I give two main answers to the question why Copernicus's De revolutionibus (1543) had so long been officially ignored in 'Rome'. The first is that cosmological issues were of only peripheral importance in such times of life-and-death contestations with Protestant reformers. The second is that it took - in a very contingent way-the personality of Cardinal Bellarmine, driven by an anti-reformationist emphasis on authority, to unite with a 'synergy effect' two separate dogmatic strands: (1) the old teaching of the superiority of theology over all other forms of knowledge, made binding in the Papal Bull Apostolici Regiminis (1513), and, (2) the Decree of the Council of Trent on the Holy Scripture (1546), which stated that only the Church, and not the single believer (as Luther had claimed), had the authority to bindingly interpret the Scripture in matters of faith and morals. The synergy between the two strands had the surprising epistemic result of any biblical passage becoming a 'matter of faith.'
\end{abstract}

Our story ends on 5 March 1616 with a Decree of the Holy Congregation of the Index: ${ }^{2}$

This Holy Congregation has also learned about the spreading and acceptance by many of the false Pythagorean doctrine, $\left[^{3}\right]$ altogether contrary to

1 Thanks to Giora Hon (Haifa) for greatly improving the paper.

2 This Congregation had been in charge of prohibiting 'dangerous' books since 1571. This was done in close cooperation with the senior Holy Office (Sanctum Officium or Sant'Uffizio, the short name of the Suprema Sacra Congregatio Romanae et Universalis Inquisitionis).

3 This relates to the conception of Philolaos (c. 420 B.c.) of a 'central fire' surrounded by the heavenly bodies, the sun included. Cf. Carrier M., Nikolaus Kopernicus (Munich: 2001) 74f. 
the Holy Scripture, that the earth moves and the sun is motionless, which is also taught by Nicolaus Copernicus's On the Revolutions of the Heavenly Spheres [...] Therefore, in order that this opinion may not creep any further [in] to the prejudice of Catholic truth, the Congregation has decided that the books by Nicolaus Copernicus [...] and Diego de Zuñiga [...] be suspended until corrected; but that the book of the Carmelite Father Paolo Antonio Foscarini be completely prohibited and condemned; and that all other books which teach the same be likewise prohibited $[\ldots]^{4}$

The decree does not mention Galileo Galilei (1564-1642) for the simple reason that he had not yet published on the subject, although it was an open secret in Rome and elsewhere since the publication of his Sidereus Nuncius (1610) that he was a staunch supporter of Copernicanism. In this little book Galileo reports the discovery of the four satellites of Jupiter. Galileo's Copernicanism became even more visible after the subsequent discoveries of the phases of Venus and Mercury. 5

Apart from these public developments, so to speak, two denunciatory letters had reached the Holy Office. ${ }^{6}$ They had set in motion a procedure part of which was a short report by no less than eleven 'consultants' (consultores) of the Holy Office:

[...] Propositions to be assessed:

(1) The sun is the centre of the world and completely devoid of local motion.

Assessment: All [consultants, G.W.] said that this proposition is foolish and absurd in philosophy, ${ }^{7}$ and formally heretical since it explicitly contradicts in many places the sense of the Holy Scripture, according to the

4 The complete text of the decree is in Finocchiaro M.A., The Galileo Affair. A Documentary History (Berkeley: 1989) 148-150, quote 149. Finocchiaro gives English translations of important documents in the context of the ecclesiastical actions against Galilei.

5 The existence of satellites of Jupiter supported the idea that the moon was not a planet but rather a satellite of the earth, while the phases of Venus and Mercury could be explained as confirmation of their orbiting around the sun.

6 The denunciations (1615) of the two Florentine Dominicans Niccolò Lorini and Tommaso Caccini are in Finocchiaro, Galileo Affair 134-141.

7 'Philosophy' in the usage of the time was understood as explanatory knowledge, as opposed to descriptive ('historical') knowledge. It included what we call 'science.'-Regarding the conceptual history cf. Kambartel F., Erfahrung und Struktur. Bausteine zu einer Kritik des Empirismus und Formalismus (Frankfurt a.M.: 1968) ch. 2. 
literal meaning of the words and according to the common interpretation and understanding of the Holy Fathers and the doctors of theology.

(2) The earth is not at the centre of the world, or motionless, but it moves as a whole and also with diurnal motion.

Assessment: All said that this proposition receives the same judgment in philosophy and that with regard to theological truth it is at least erroneous in faith. ${ }^{8}$

Given Galileo's reputation as a Copernican, it was no surprise that Cardinal Robert Bellarmine (1542-1621), one of the Cardinal Inquisitors, summoned him to the Holy Office on 26 February 1516, i.e. still prior to the promulgation of the decree. Bellarmine, among other things, had earned a reputation in the trial that brought Giordano Bruno (1548-160o) to the stake,

in the name of His Holiness the Pope and the whole Congregation of the Holy Office, ordered and enjoined the said Galileo, who was himself still present, to abandon completely the above-mentioned opinion that the sun stands still at the centre of the world and the earth moves, and henceforth not to hold, teach, or defend it in any way whatever, either orally or in writing; otherwise the Holy Office would start proceedings against him. The same Galileo acquiesced in this injunction and promised to obey. ${ }^{9}$

As we know, Galileo did not obey in the long run and was sentenced to prison for life (1633). The Roman wolves, finally, had howled triumphantly. Why had they been quiet for so many years? Why did it take them so long to identify Copernicanism as a severe menace to faith? This brings us to the beginning of our story.

\subsection{The Pre-Copernican Situation}

The story begins with Nicolaus Copernicus (1473-1543) who, after studying in Cracow, Bologna, Padua and Ferrara, spent most of his life in Frauenburg

8 Finocchiaro, Galileo Affair 146. The assessments of 1616 return almost literally in the judgment of the Inquisition against Galileo of 22 June 1633 (cf. Finocchiaro, Galileo Affair 288) - 'Formally heretical' refers to an opinion of which the person who utters it knows that it is heretical, that is, explicitly ('formaliter') refuses to acknowledge the 'truth.'

9 Bellarmino's special injunction against Galilei in Finocchiaro, Galileo Affair $147 \mathrm{f}$. 
(Frombork), ${ }^{10}$ Ermland (Varmia), as an ecclesiastical administrator ('Canon'), without having taken holy orders, however. Apart from this, the humanist Copernicus was active as a medical practitioner and amateur astronomer. This means that the person who launched the 'Copernican Revolution' was not at all a professional astronomer at a university or a court. He was also not much of a revolutionary personally; rather, he was anxious to save as much of the old astronomy and physical cosmology as possible. In order to assess his contribution correctly we must first present the main features of the astronomical theory he wanted to improve by introducing one important change, while at the same time saving its conceptual foundations. ${ }^{11}$ Secondly, the methodological aspects of Copernicus's move, related to the philosophy of science, will be discussed.

First we must distinguish three basic disciplines that are interwoven almost inextricably in astronomical practice: (1) astronomy, ${ }^{12}$ (2) natural philosophy, consisting of a) cosmology, b) (terrestrial) physics, and (3) theology. There is a progressive order of subordination here in the sense that the ultimate explanatory principles of astronomy are to be found in natural philosophy, while those of natural philosophy are to be found in theology. ${ }^{13}$ We will later see that these distinctions were of great importance to the ecclesiastical authorities. Astronomy is the discipline that renders data about the positions of heavenly bodies and develops mathematical means to calculate, for example, their future positions or the time that elapses before the same relative positions return (vulgo a year), and so on. Basically, astronomy is a kind of applied

10 Upon their first occurrence, place names are given in German and Polish; later, only in German. Here I follow Hooykaas R., G.J. Rheticus'Treatise on Holy Scripture and the Motion of the Earth (Amsterdam: 1984) 2.

11 There are several good introductions to Copernicus. I have mostly used Carrier, Kopernikus, a reliable book also for the non-specialised reader; it focuses on methodological questions. The best English introduction is arguably Gingerich O., The Eye of Heaven: Ptolemy, Copernicus, Kepler (New York: 1993). Also very useful is Goddu A., Copernicus and the Aristotelian Tradition: Education, Reading, and Philosophy in Copernicus's Path to Heliocentrism (Leiden: 2010); Swerdlow N.M. - Neugebauer O., Mathematical Astronomy in Copernicus's De revolutionibus, 2 vols. (New York: 1984) requires advanced astronomical (and mathematical) understanding.

12 Westman R.S., The Copernican Question: Prognosticism, Skepticism, and Celestial Order (New York: 2011) 17f. prefers 'heavenly (celestial) practitioners' to 'role designators like scientists or men of science' or 'astronomers', for that matter. Westman is certainly hermeneutically correct, but for simplicity's and brevity's sake, as well as to facilitate distinctions, I use the above categories.

13 Cf. Barker P., "The Role of Religion in the Lutheran Response to Copernicus," in Osler M. (ed.), Rethinking the Scientific Revolution (Cambridge: 2000) 59-88, particularly 7xf. 
mathematics, more geometry than physical science. Consequently, astronomy says nothing about the 'true causes' of the observed phenomena. Astronomical reasoning from observed effects can at best lead to possible causes.

By and large, Copernicus was a follower of the astronomy of the Greek scholar Ptolemy (second century A.D.) as laid down in the latter's Almagest. We will soon see at which point Copernicus disagreed with his authority.

Natural philosophy is a discipline that, other than astronomy, can give us true causes. As long as natural philosophy is occupied with heavenly motions - that is, as long as it is cosmology - it consists in our context of virtually axiomatic ontological assumptions about the structure of the universe and the motions going on in it. I would like to mention four such assumptions, which were widely shared:14

(1) the earth occupies the central position of the whole universe;

(2) all heavenly bodies display a uniform, circular motion around the earth, or their motion is composed of uniform and circular parts;

(3) the 'planets'15 are fixed on moving, completely transparent crystal spheres;

(4) the fixed stars are fixed to an outermost sphere, which annually revolves around the earth. Natural philosophy, understood as physics, is a metaphysical theory of 'sublunar' motions, i.e. motions of terrestrial bodies. It comes into play above all when one wants to test for terrestrial motions the presumed consequences effected by a moving earth, as one would have to within a heliocentric system. ${ }^{16}$

The primary task of astronomy was to account for the observations recorded in tables and calendars. Basically two strategies were used to achieve this: first, to follow the 'instrumentalist' program of 'saving the phenomena.'17 Sixteenth-century astronomers widely shared the belief that there was no way

14 Cf. Carrier, Kopernikus 29 .

15 Note that in the geocentric system the sun and the moon are also 'planets'.

i6 Cf. Carrier, Kopernikus $39 f$.

17 The use of the nineteenth-century (P.Duhem) realism/instrumentalism distinction in the philosophy of science has been justly criticised by Barker P. - Goldstein B.R., "Realism and Instrumentalism in Sixteenth Century Astronomy: A Reappraisal", Perspectives on Science 6 (1998), 232-258. The authors claim that the present understanding of the distinction does not cover what was at stake in the sixteenth century. I agree with the authors about the anachronism of applying the realism/instrumentalism distinction. I believe, however, that there is a considerable overlap between this and the demonstratio quia/demonstratio propter quid distinction: the fact that knowledge of true causes claimed to give an account 
to demonstrate propter quid, meaning true causes. One had to be content, so the 'instrumentalist' position went, with quia demonstrations, in which reasoning goes from observations to only possible causes. Consequently, for the time being cosmological conceptions had to be regarded as 'hypotheses.' This advisable ontological epoché notwithstanding, there existed, second, a large number of realistic cosmological claims from the very beginning: Ptolemy in the Almagest generally followed the hypothetical-instrumentalist option, whereas in his Planetary Hypotheses he presented his set of nested spheres as a physical realisation of the universe, that is, as cosmology.

Theology comes into play when astronomy and natural philosophy have to be embedded in what one presumes to know about God's plan of creation.

To account for the above-mentioned 'axiomatic' assumptions, particularly the uniform, circular motion of the heavenly objects, Ptolemaic astronomy in its calculations used the following: (1) the deferent-epicycle-system; ${ }^{18}(2)$ the eccentric orbits of 'planets,' that is, orbits around the earth where the earth is not, however, at the centre; (3) so-called equants, introduced by Ptolemy himself.

The deferent-epicycle system, in order to account for the irregular motions of the 'planets', superimposes two uniform and circular motions: first of all, the 'planet' moves in a circular orbit ('deferent') around the earth as the centre of the universe; second, the planet itself, however, does not move along the deferent but rather the centre of a second orbit ('epicycle'), along which the 'planet' is thought to move (Fig. 2.1).19

However, this ingenious system did not suffice in the case of Mars, and was not necessary for the Sun and other planets, whose motion could be described equivalently by simply moving the centre of their orbits away from the earth to an 'eccentric' point close to it (Fig. 2.2), thus rendering the system geostatic rather than geocentric. In fact, Ptolemy in the case of the 'planet' Sun preferred the eccentricity hypothesis as 'simpler' because it involved only one motion and not two, as in the deferent-epicycle model.

The motion of the planet Mars required, finally, a third trick: Ptolemy could uphold the uniform motion of the epicycle's centre only by having it move with uniform angular motion around 'a point equal and opposite from the

of how the heavens really are, while knowledge of possible causes lead only to 'hypotheses' on how the heavens may possibly be.

The epicycle-deferent system as well as the idea of orbital eccentricity was based on respective considerations of Apollonius in a lost work (cf. Gingerich, Eye of Heaven 7-9.). As indicated earlier in realistically interpreted models, in antiquity it is not the 'planets' themselves which move but rather the spheres to which they are fixed. 


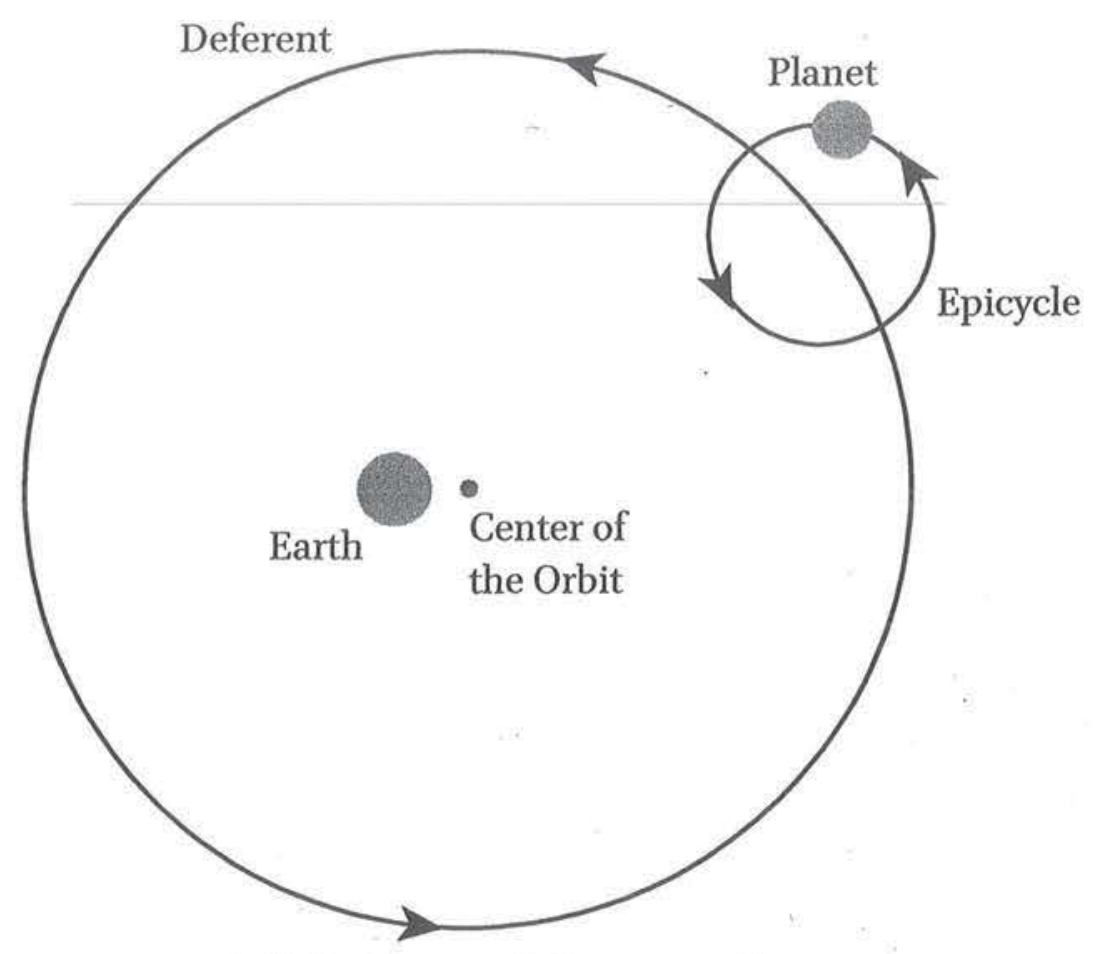

FIGURE 2.1 Siobahn Morgan, Deferent-epicycle system

(open source lecture course material), taken from: http://www.uni.edu/morgans/astro/course/notes/ sectionı/new3.html.

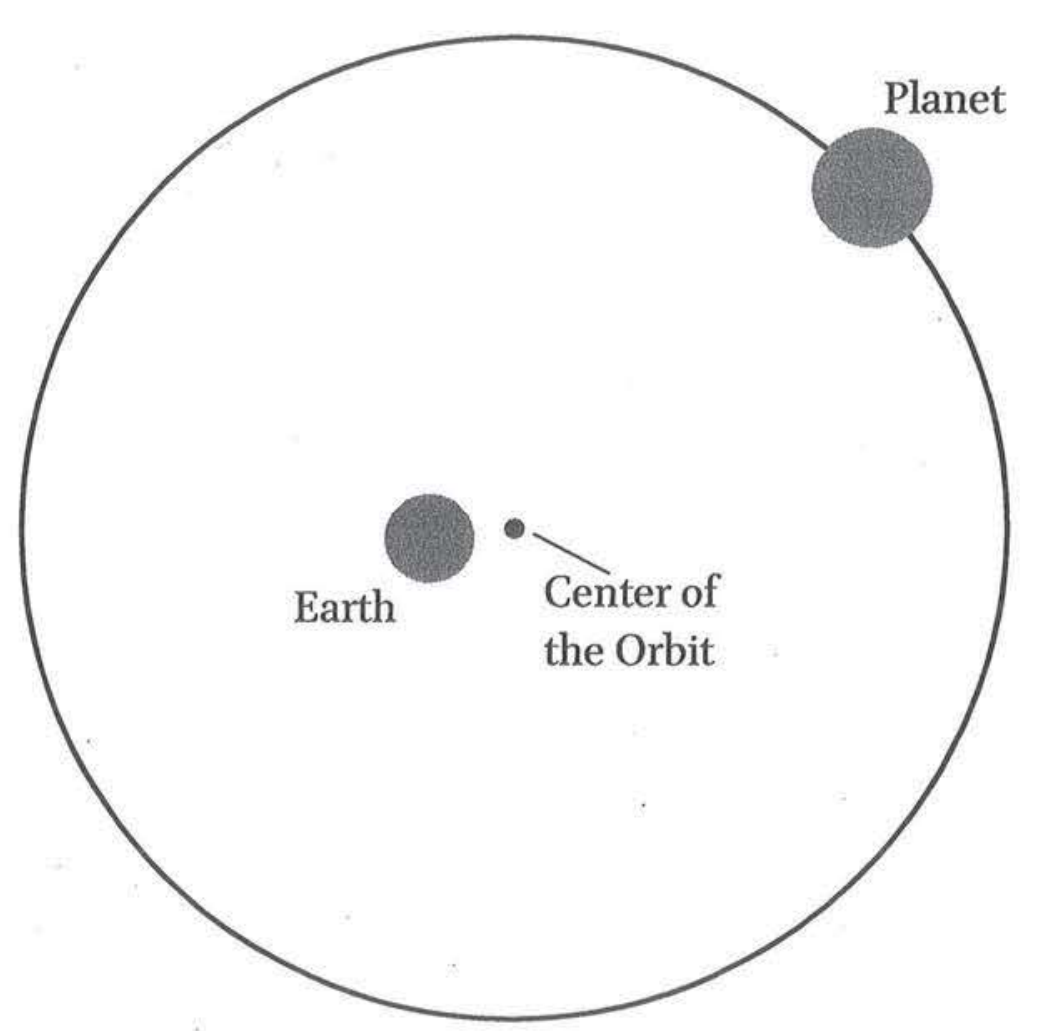

FIGURE 2.2 Siobahn Morgan, Eccenter model

(open source lecture course material) taken from: http://www.uni.edu/morgans/astro/course/ notes/sectionz/new3.html. 


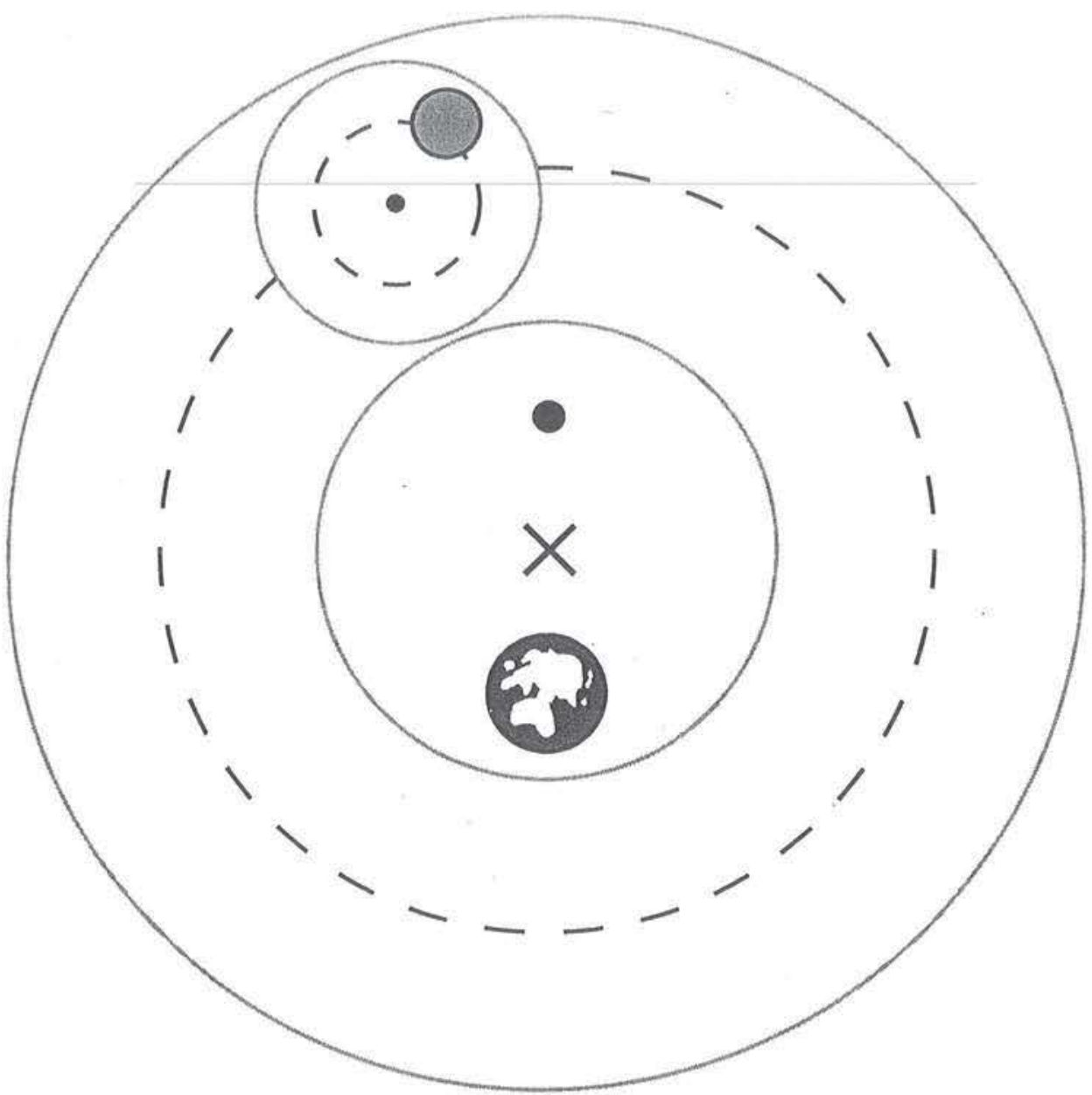

FIGURE 2.3 The basic elements of Ptolemaic astronomy, showing a planet on an epicycle (smaller dashed circle), a deferent (larger dashed circle), and an equant (larger black dot); " $x$ " marks the eccenter, while the large black dot represents the earth (taken from Open Source Wikipedia: "Deferent and epicycle" [February 2014]).

earth along the line through the deferent centre. ${ }^{20}$ The equant is shown below in Fig. 2.3 together with the other two ingredients of Ptolemy's attempt to save the phenomena.

This, painted in rather broad strokes, was the situation that Copernicus encountered when he entered the scene. Our question is, what did he change and why? 
2.2 Copernicus's Innovations

Copernicus changed, first in his Commentariolus (a manuscript sent to a few friends and written prior to 1514$)^{21}$ and much later in De revolutionibus (1543), the first of the above-mentioned 'axiomatic' assumptions of pre-Copernican thinking - the central position of the earth is now assumed by the sun..$^{22}$

The remaining basic assumptions were retained, except the one concerning the outermost sphere carrying the fixed stars. It no longer revolves but remains at rest.

What did Copernicus gain by placing the sun at rest? I would like to mention three points, each of which shows that Copernicus saw the advantage of his system mainly in its simpler and therefore sounder methodology:

(1) He provides a new explanation for the retrograde motion of the outer planets, i.e. Mars, Jupiter and Saturn. ${ }^{23}$ While in the Ptolemaic system one needs separate complicated assumptions for each planet, in the Copernican system the retrograde motions of the outer planets are a direct consequence of the theory, that is, the motion of the earth, when it overtakes an outer planet in its common orbit around the sun. ${ }^{24}$ It is this extraordinary explanatory unification, as it is called in contemporary philosophy of science, which is the most important result of heliocentrism in this context and arouses an almost poetic enthusiasm in Copernicus:

In this arrangement, therefore, we discover a marvellous symmetry of the universe, and an established harmonious linkage between the motion of the spheres and their size, such as can be found in no other way. [...]

21 The best English translation of the Commentariolus, together with an excellent commentary, is arguably Swerdlow N.M., "The Derivation and First Draft of Copernicus's Planetary Theory: A Translation of the Commentariolus with Commentary", Proceedings of the American Philosophical Society 117 (1973), 423-512.

22 On the complicated history of the publication of De revolutionibus see Gingerich O., The Book Nobody Read: Chasing the Revolutions of Nicolaus Copernicus (London: 2004). This book is, incidentally, a fascinating account of Gingerich's sleuthing (even the Russian mafia enters) in order to trace surviving copies of the first (1543) and second (1566) editions of De revolutionibus. Gingerich gives an account of his findings, particularly about the most important margins, in idem, An Annotated Census of Copernicus's De revolutionibus (Nuremberg, 1543 and Basel, 1566) (Leiden: 2002).

23 Cf. Carrier, Kopernikus 89-94.

24 In addition, another old problem, namely the maximum luminosity of the outer planets, is solved: when overtaking a planet, the earth is in its nearest position to that planet. Consequently the planet displays its maximum luminosity. 
All these phenomena [unified under the heliocentric hypothesis, G.W] proceed from the same cause, which is the earth's motion. ${ }^{25}$

(2) He gives a new explanation of the restricted elongation of the inner planets. ${ }^{26}$ While the elongation of the outer planets can reach $180^{\circ}$, that of the inner planets does not exceed $28^{\circ}$ (Mercury) and $47^{\circ}$ (Venus), which is at the same time a consequence of their sequential arrangement in the heliocentric system. ${ }^{27}$ While these and other related phenomena require assumptions from one planet to the other in the geocentric system, they follow directly just from the very geometry of Copernican heliocentrism that here again leads to a remarkable explanatory unification.

(3) He asserts that the equant, introduced by Ptolemy in order to save the principle of uniform motion and arguably the most unpopular ${ }^{28}$ ingredient of the Ptolemaic theory, is no longer needed in his system and he explicitly rejects it (book v, ch. 25). ${ }^{29}$

Thus far everything looks fine. But when it comes to reconciling this beautiful explanatory unification with the dry figures of astronomical observations, Copernicanism looks no better than the Ptolemaic system in meeting the 'gold standard' (then and now) of theory assessment: empirical adequacy. Rather, Copernicus had to introduce an apparatus of epicycles and eccentrics similarly complex as its Ptolemaic rival, in order to account for the observations. This was mostly due to the fact that he insisted on uniform and circular motion,

25 Copernicus Nicolaus, On the Revolutions, trans. E. Rosen, ed. J. Dobrzycki (London: 1978) 22. Nonetheless, Copernicus needs many epicycles in order to determine the exact position of a planet (cf. Swerdlow, "Commentariolus" 510).

26 The elongation of a planet is the angle between the sun and the planet, as viewed from the earth.

27 For B.R. Goldstein in his "Copernicus and the Origin of His Heliocentric System", Journal of Astronomy 33 (2002) 219-235, the sequential order of the planets, based on the "key principle $[. .$.$] that the periods of planets are longer as their orbs are farther from the cen-$ tre of motion', that is, the sun (220), was Copernicus's decisive initial motive for proposing the heliocentric hypothesis. This is also true of Westman's Copernican Question $139 \mathrm{f}$.

28 The unpopularity of the equant lies in the fact that in a sense it 'cheated' about uniform motion because it 'saved' only uniform angular motion. However, this means that epicycles move at different speeds depending on whether their deferent is closer or farther away from the equant point. In the first case they move more slowly and in the second, faster because the centre of the epicycle must travel along a longer segment on the deferent. A very good illustration is in Gingerich, The Book 51-53.

29 One must note, however, that Muslim astronomy had produced 'many models that resolved the problem while maintaining a geocentric framework' (Goldstein, 'Copernicus and the Origin" 220). 
while planets in actual fact move on elliptical orbits in a non-uniform way, as Kepler would show later.

While the methodological virtues of the explanatory unification and simplicity of Copernicus's system did not make much of an impression on his contemporaries, its instrumental value both for the Gregorian calendar reform and for better astronomic tables was significant and widely respected. ${ }^{30}$

3

\section{Reactions of the Religious Authorities ${ }^{31}$}

\subsection{The Preventive Measures of Copernicus \& Friends}

In retrospect it is hardly understandable why Copernicus's cosmological innovations could ever collide with religious authority. They were protected by the most venerable teachings of how to read the Bible. In his commentary on the book of Genesis, St. Augustine had already strongly recommended an allegorical, i.e. figurative, understanding of biblical passages that do not relate to faith and morals and are at variance with highly certain results of reasoning or with empirical evidence. ${ }^{32}$ By the late Middle Ages this and related approaches had led to the teaching of a 'fourfold sense of Scripture' (quattuor sensus scripturae), meaning that a literal reading of the Bible was just one way of understanding its texts; in many cases allegorical, moral or eschatological readings were also possible, and often unavoidable. ${ }^{33}$

Nonetheless, some friends of Copernicus, however, and probably the master himself, saw dangers on the horizon. Most important in this respect is the young Protestant Wittenberg scholar Georg Joachim Rheticus (1514-1574). In 1539 Rheticus went to Frauenburg for almost two and a half years, thus becoming Copernicus's first and only pupil, regarding him as a sort of master and

30 Cf. Carrier, Kopernikus 137. However, this did not include an acceptance of the Copernican system.

31 A good presentation of such reactions is Lerner M.-P., "L' « hérésie » héliocentrique: du soupçon à la condamnation", in Sciences et religions. De Copernic à Galilée (1540-1610). Actes du colloque international organisée par l'Ècole française de Rome. En Collaboration Avec L'Ecole Nationale Des Chartes Et L'Istituto Italiano per Gli Studi Filosofici, Avec La Participation De L'Universita Di Napoli Federico II (Rome: 1999) 69-91. certissima ratione vel experientia (Aurelius Augustinus, Über den Wortlaut der Genesis, vol. I (Paderborn: 1961) 32 (ch. 19, no. 39).

Cf. Stuhlmacher P., Vom Verstehen des Neuen Testaments. Eine Hermeneutik (Göttingen: 1979) $\S \S 6,7$, which gives an overview of the historical development. 
even father. ${ }^{34}$ In 1540 Rheticus published a sketch of Copernicus's theory, the Narratio prima, which at the same time was the first printed account of Copernicus's heliocentric system. ${ }^{35}$ At the same time he was able to convince Copernicus to publish De revolutionibus. When in 1541 Rheticus left Frauenburg for Wittenberg where he became the most vocal propagandist of Copernicus's system, the manuscript was in his baggage. Also in his baggage, however, was a defence (De terrae motu $)^{36}$ against possible theological attacks.

Rheticus's argumentative strategy in De terrae motus shows almost all the ingredients one later finds with other defenders of Copernicanismmost prominently Galileo Galilei in his famous letter to the Grand Duchess Christina (1615) - as follows. ${ }^{37}$ (1) Presenting oneself as a strict follower of Saint Augustine with respect to the methods of Scripture interpretation. ${ }^{38}$ This included admitting the allegorical sense along with the literal sense of the Scripture, and above all emphasising what Hooykaas calls 'accommodation' ${ }^{39}$ This means that the Holy Texts are not scientific textbooks but books of religious and ethical instruction. Where they refer to natural things they must accommodate the understanding of the man in the street (sections 1-13). (2) Quoting passages from the Bible that might support the idea of a moving earth with the sun at rest. This is a clever move, intended to neutralise the strategy of potential opponents, again emphasising accommodation (sections 14-27). (3) Epistemologically and theologically reflecting about sense perception and the Scripture and securing a place for science by stating that, with respect to everything 'beyond the range of the senses (extra sensum) [...]

34 The reference to Copernicus as his 'master' (praeceptor) is found in many places in the Narratio prima (see below) and other writings. As to Rheticus's explicit use of the term 'father' with respect to Copernicus cf. the quote in Hooykaas, Rheticus' Treatise 150. Rheticus's biological father, a town physician at Feldkirch in what is now Austria, was executed for stealing from his patients when Rheticus was 14 years old. Danielson D., The First Copernican: Georg Joachim Rheticus and the Rise of the Copernican Revolution (New York: 2006) provides a good account of the relationship between the two men.

35 Critical edition of the Latin text in Copernicus Nicolaus, Gesamtausgabe vol. viII.1, 5-56.

36 The text that had been printed anonymously only in 1651 was discovered and identified by the Dutch historian of science Reijer Hooykaas and published together with an English translation, notes and an extensive commentary in 1984 (see Bibliography, Hooykaas).

37 English Text in Finocchiaro, Galileo Affair 87-118.

38 However, it seems that Copernicus and his associates were not realistic enough to see that Augustine's criteria - highly certain results of reasoning' or 'empirical evidence'-were still largely missing from the Copernican system.

Hooykaas, Rheticus' Treatise 33. 
we simply accept the Scriptures (simpliciter Scripturae acquiescimus) 40 (sections 28-32). (4) Showing that many geographical passages of the Bible had long ago been proven to be wrong without anyone shouting 'heresy' (sections $33-43) \cdot{ }^{41}$ Finally (6), again stressing accommodation as the adequate means of interpreting passages that seem to support the centrality of a nonmoving earth. Such passages are better understood allegorically rather than literally (sections 44-64).

For the rest, Rheticus emphasises six times 'that he remains within the bounds of the Catholic Faith.42 This 'catholicity' of the Lutheran Rheticus shows, in addition to the tactical aim of possibly protecting his master, that the Reformation process at the time of the publication of De revolutionibus, i.e. around 1540, had not yet reached a point of complete rupture from 'Rome'. Many still regarded the Reformation as a movement within the Church. At the same time, however, those forces that envisaged a complete separation were at work on both sides. At the end of the Council of Trent (1563), 24 years after Rheticus's arrival at Frauenburg, it seems inconceivable that a Lutheran from Wittenberg would choose a Catholic Canon as his personal teacher and harmoniously live with him for more than two years.

Copernicus most probably knew about Rheticus's preventive defence (against the theologians) of the conception of a moving earth. From his own pen he added a dedication to De revolutionibus for Pope Paul III, asking pontifical support against 'ignorant babblers' (mataiologoi) who pronounce judgements on cosmology badly distorting some passage of Scripture for their purposes. ${ }^{43}$

Apart from this, Osiander's preface, too, which presented (against the intention of Copernicus and Rheticus) Copernicus's system as 'hypothetical', that is, as a mathematical device directed at nothing more than 'saving the phenomena,' would serve as a firewall to keep the Roman wolves at bay, although several persons had noted its contradiction with the text that followed.

Copernicus supplemented these defensive devices-agreement with the exegetical principles of tradition, the dedication to the Pope and Rheticus's

$40 \quad$ Ibidem $52(80)$.

41 E.g., the flatness of the earth, the non-existence of antipodes, etc. On the antipodes, cf. Mayaud P.-N., Le Conflit entre l'astronomie nouvelle et l'Écriture Sainte aux Xvi et Xvir ${ }^{\mathrm{e}}$ siècles. Un moment de l'histoire des idées autour de l'affaire Galilée, 6 vols. (Paris: 2005) vol. I, 91-107. Hooykaas, Rheticus' Treatise 144f. Copernicus, Revolutions 5 . 
outline of how to win a possible controversy - by inserting into De revolutionibus a respectful letter dated 1st November 1536 by Nicolaus Schönberg, then a leading cardinal at the court of Pope Clement VII, asking him to have his work, i.e. the still unpublished De revolutionibus, copied at Schönberg's expense and sent to Rome. This letter, in turn, was to do with the fact that Copernicanism had already been introduced to the papal court in 1533, most probably only on the basis of the unpublished Commentariolus. Clement had learned in the Vatican gardens, in the presence of two cardinals, a bishop and the pope's physician, of the new theory from his secretary, the Bavarian Johann Albrecht Widmanstetter (1506-1557) ${ }^{44}$ By the time of the publication of De revolutionibus (1543), however, both Schönberg and Clement vir had died.

These defensive devices were supported by the fact that in those days the Church was almost exclusively concerned with other problems central to Catholic faith and discipline, and with how to contain the Protestant reformation. If one had to describe the catholic counter-reformation in just one word, it would be authority. The counter-reformation was about regaining authority with respect to discipline, faith and morals within the Church, thereby stopping the advance of Protestantism and possibly regaining lost territory. ${ }^{45}$

\subsection{Two Early Whistle-Blowers Die}

Despite all precautionary measures, however, there were vigilant wolves that howled but were not heard: two Dominican Fathers, the Florentine Giovanni Maria Tolosani (1470/71-1549), and his friend, the influential Master of the Sacred Palace, ${ }^{46}$ Bartolomeo Spina († 1547), gave early warnings. Together, the men could immediately have made Copernicanism a target of the authorities had they not died before they could take action-perhaps a work of Providence. Tolosani's respective anti-Copernican manuscript (1646/47) rested undisturbed in what is now the Biblioteca Nazionale of Florence. It is under the title Opusculum quartum, constituting a portion of a major bundle of apologetic writings, the first part of which contains a letter of approbation dated

44 As a reward for his lecture in the Vatican gardens, Clement viı presented him with a book; on the title page Widmanstetter proudly reports the story of this pontifical present; $\mathrm{cf}$. Prowe, Nicolaus Coppernicus (reprint Osnabrück: 1967) I.2 274.

45 This is my reading of Jedin H., "Katholische Reform und Gegenreform", in Jedin H. (ed.) Reformation: Katholische Reform und Gegenreformation (Freiburg: 1967) 449-604.

46 The Master of the Sacred Palace was a sort of leading theologian in the Vatican (not the Holy Office); among other things he was in charge of the prohibition of books. 
August 6,1546 by Bartolomeo Spina. ${ }^{47}$ Tolosani's Opusculum is dedicated to the same Paul III to whom Copernicus had dedicated De revolutionibus. What was it about the latter that had raised the suspicion of the two Dominicans?

It is easily conceivable that with respect to De revolutionibus Spina was alarmed for two reasons: (1) the book was dedicated to the Pope with an appeal for protection against theologians ignorant in astronomy (like Spina himself); (2) the book was printed in Nuremberg, 'citadelle du luthéranisme' (Lerner), and its publication coincided with the ban on importing 'Protestant' books. ${ }^{48}$ Apart from this, Spina had clear ideas about the methodological ranking of disciplines: in 1525 he had published a book with the telling title Treatise on the Preeminence of Holy Theology over All Other Sciences, Above All Those of Human Laws. ${ }^{49}$ Tolosani, in turn, was, among other things, an astronomer. He had contributed to the first attempt at a calendar reform in the context of the fifth Lateran Council, where Copernicus had also been asked to contribute.

Tolosani ${ }^{50}$ begins (largely following the anti-Copernican roadmap anticipated by Rheticus) by quoting biblical passages about cosmology all unfavourable to Copernicanism. He then gives a short exposition of Book 1 of $D e$ revolutionibus and criticises Copernicus for his ignorance of philosophy and theology. He continues by representing the true astronomical and physical account as given by Ptolemy and Aristotle. He concludes with an attitude of resignation:

The Master of the Holy and Apostolic Palace [i.e. his friend Spina] thought of condemning his [i.e. Copernicus's] book. But first sickness and then his death prevented him from implementing this. I, then, thereafter in

The Latin text was identified and edited by Garin E., "Alle origini della polemica anticopernicana," Studia Copernicana 6 (1973) 31-42. On Tolosani I follow Lerner M.-P., "Aux origins de la polémique anticopernicienne (I): L'Opusculum quartum de Giovanmaria Tolosani (1547-1548)", Revue des sciences philosophiques et théologiques 86, 4 (2002) 681$722,683-691$.

Cf. Lerner, “Origines (I)" 685 f.

49 Tractatus de praeeminentia Sacrae Theologiae super alias omnes scientias \& praecipue humanarum legum, cf. Lerner, "Origines (I $)^{n} 685$. Here, Spina follows the path of the Papal Bull 'Apostolici regiminis' of 1513, which had succinctly stated that 'every assertion that contradicts illuminate faith is completely wrong'; see Denzinger H. - Hünermann P. (eds.), Enchiridion Symbolorum definitionum et declarationum der rebus fidei et morumKompendium der Glaubensbekenntnisse und kirchlichen Lehrentscheidungen, 4oth edn. (Freiburg: 2005) 483 (no. 1441). 
opusculum undertook to accomplish it in order to protect the truth for the common benefit of the Holy Church. ${ }^{51}$

Lerner's evaluation that the Church observed a 'neutralité bienveillante' can hardly be supported. ${ }^{52}$ The 'Church' was in no way "neutral" but rather simply not involved. Tolosani's text and Spina's willingness to condemn Copernicus remained completely unknown. The first formal Roman Index of Prohibited Books, issued in 1559 by Pope Paul IV, also does not mention Copernicus or any other Copernican, and neither does the Index of the Council of Trent (1564). ${ }^{53}$ In the same vein, the Index Congregation, established in 1571, was not put into action by the sleeping Roman wolves. ${ }^{54}$

In any case, it is interesting to note that in 'Rome' it was not only a lack of interest and competence that hindered dealing with Copernicanism, but also contingent factors such as the premature death of two of its most dogged enemies.

\subsection{An Abject Attempt to Ban Copernicanism}

Apart from Tolosani and Spina, there is only one rather insignificant indication of anti-copernican activities in the Archives of the Holy Office and the Congregation of the Index. In the introduction to the section on Copernicus, in their extremely valuable and meritorious collection of documents on the Church and science, Baldini and Spruit give a fitting evaluation: 55

51 'Cogitaverat magister sacri et apostolici paltii eius improbare librum, sed prius infirmitate, deinde morte praeventus, hoc implere non potuit. Quod ego postea in hoc opusculo perficere curavi pro veritate tuenda in communem ecclesiae sanctae utilitatem.' Lerner, "Origines (I)" 719 .

52 Lerner, "Origines (I)" 682.

53 I follow Wolf H., Index. Der Vatikan und die verbotenen Bücher (Munich: 2006) 26f., a 'nearentertaining' book written by arguably the greatest expert on the Archives of the Holy Office and the Congregation of the Index.

Only in 1613 did Tommaso Caccini (1574-1648), a Dominican preacher of hate in Florence, use Tolosani's text in a sermon in Santa Maria Novella to stir up hatred against Copernicanism and Galileo (Cf. Westman, Copernican Question 197).

Baldini U. - Spruit L. (eds.), Catholic Church and Modern Science: Documents from the Archives of the Roman Congregations of the Holy Office and the Index, vol. I (Sixteens Century Documents) in 4 parts (Vatican City: 2009) 1.2 1473-1480, quotes on 1473. Joseph Ratzinger, then Prefect of the Congregation for the Doctrine of the Faith, made the archives of the Holy Office and the Congregation of the Index accessible to researchers only in 1998. 
There is frequently a large gap between the importance of an author, at least as it appears today, and the amount of Censorial interventions regarding his works, usually depending upon the intellectual and cultural views of the Censors, upon the intrinsic limitations of available information, and upon a lack of competence in specific fields other than theology and scholastic philosophy. Among the authors and doctrines virtually ignored by the Roman Congregations during the sixteenth century, Copernicus (1473-1543) and heliocentrism represent without doubt the most salient case.

Indeed, in the Archives has survived only an 'extremely short expurgatory censura' of the second edition of De revolutionibus (Basel 1566), proposed by a censor in Naples in 1598. It has neither Copernicus's name right, nor the title of the book, and was directed not against Copernicus and De revolutionibus but rather the 'heretic' Rheticus and his Narratio prima with which it was bound together:

Ex operis Nicolai Caprearij volutionibus orbium, Basileae, Henrici etc deleatur ${ }^{56}$ 1566. Deleatur narratio per Georgium Ioachinum Raicum [i.e. Rheticum, G.W.] Ereticum. ${ }^{57}$

Given that no action of the Holy Office resulted from this short note from Naples, the editors come, finally, to the fair summary that,

the Congregations seem to have been virtually unaware of the significance of Copernicanism, and the very few members who were acquainted with Copernicus's central views, as a rule, deemed the latter as utterly absurd, and certainly not a substantial challenge to the traditional interpretation of Biblical cosmology and its intimate link to Aristotelian natural philosophy. ${ }^{58}$

56 The 'deleatur' refers to cancelling the name of Basel and the printer's name.

57 Baldini - Spruit, Catholic Church I.2 1481 comment: "The scribe was probably an ecclesiastic with a fairly limited education and with poor knowledge of Latin, who did not grasp what he was copying.'

$5^{8}$ Baldini - Spruit, Catholic Church I.2 1478. The Naples censura is not mentioned in Mayaud P.-N., La condamnation des livres Coperniciens et sa révocation à la lumière de documents inédits des Congrégations de l'Index et de l'inquisition (Rome: 1997). The first three chapters of the book inform about the structure and activity of the Congregation of the Index. 

The hardening of the ecclesiastical line against Copernicanism has its main roots in the Council of Trent $\left(1545^{-1563)}\right.$, which aimed at reforming the Catholic Church, thereby giving rise to the counter-reformation by strengthening the principle of authority. ${ }^{59}$ The first session (1546) was devoted to the Scripture. This was indeed an issue that deeply divided Catholics and Protestants. To be sure, both sides shared the humanist dedication to philological scholarship that was directed to and favourable of a literal understanding of the texts. That Protestant reformers based faith on the Scripture alone (sola scriptura) corresponded well with this. They understood the Scripture as a literal expression of 'God's word,' accessible to everybody without any interference from theological or other authorities. The Catholic Church, however, reacted to this exegetic anarchy in the Protestant camp: the Scripture together with its authoritative interpretation by the Church and the Fathers of the Church were declared the basis of Catholic faith:

Furthermore, to control petulant spirits, the Council decrees that, in matters of faith and morals pertaining to the edification of Christian doctrine, no one, relying on his own judgment and distorting the Sacred Scriptures according to his own conceptions, shall dare to interpret them contrary to the sense which Holy Mother Church, to whom it belongs to judge of their true sense and meaning, has held or does hold, or even contrary to the unanimous agreement of the Fathers, even though such interpretations should never at any time be published. Those who do otherwise shall be identified by the ordinaries and punished in accordance with the penalties prescribed by the law. ${ }^{60}$

Note that the ecclesiastical authority with respect to controlling the Scripture is still restricted to 'matters of faith and morals' - quite in the spirit of St. Augustine and the subsequent exegetical development. Although the text of the Council says nothing about methods of interpretation and only interpretative authority, 'some theologians of the late sixteenth century read this passage to assert the primacy of literal interpretation. ${ }^{61}$ It is above all Bellarmine who

\footnotetext{
59 The Council met in three sessions (1545-47, 1551-52 and 1559-63).

6o Translation in Blackwell R.J., Galileo, Bellarmine, and the Bible. Including a Translation of Foscarini's Letter on the Motion of the Earth (Notre Dame: 1991) 183. Latin original in Denzinger - Hünermann, Enchiridion 498 (no. 1507). 
theologically advances the primacy of literal meaning. ${ }^{62}$ At the same time, Bellarmine is the man behind the condemnation of Copernicanism. But something prevents him from striking right away: Copernicanism as a cosmological view does not yet relate to faith and morals.

In order to achieve this, the second dogmatic strand was used very effectively. It concerns the old question of 'double truth' that had come up only recently in the context of the timely condemnation of Pietro Pomponazzi's (1462-1525) De immortalitate animae. In the Papal Bull Apostolici regiminis (1513) in the context of the Fifth Lateran Council, Leo X, with an eye on the immortality of the soul, had arrived at a rather general statement:

Since truth cannot contradict truth, we define that every statement contrary to the enlightened truth of the faith is totally false. ${ }^{63}$

This seems to be the boldest and most authoritarian epistemological claim the Church has ever made in an officially binding document. What was still needed, however, was to bring 'Trent' and Leo $\mathrm{x}$ together. It took the smart and at the same time authoritarian Bellarmine to accomplish this feat. In my view, his stroke of genius was to interpret the 'illuminated faith' of Apostolici regiminis as being directly communicated by the Holy Spirit. In a letter to Foscarini (1615), who together with Copernicus was to end up on the Index a year later, Bellarmine declares:

Nor can one reply that this [i.e., Copernicanism] is not a matter of faith, because even if it is not a matter of faith because of the subject matter, it is still a matter of faith because of the speaker [i.e. the Holy Spirit through the authors of Scripture]. Thus anyone who would say that Abraham did not have two sons and Jacob twelve would be just as much of a heretic as someone who would say that Christ was not born of a virgin, for the Holy Spirit has said both these things through the mouth of the Prophets and the Apostles. ${ }^{64}$

62 Blackwell, Galileo ch. 2.

63 Denzinger - Hünermann, Enchiridion 483 (no. 1441). - The Latin text as an appendix is also in Constant E.A., "A Reinterpretation of the Fifth Lateran Council Decree Apostolici regiminis (1513)", Sixteenth Century Journal 33, 2 (2002) 353-378. The English translation of the quote is on p. 363 .

64 Blackwell, Galileo 105; see also Finocchiaro, Galileo Affair 68. 
Blackwell draws the correct conclusion that according to this position,

every statement in Scripture, once its correct literal meaning has been established, is a de fide truth' and includes 'also historical and empirical matters in the Bible on which there happens to be agreement in the Church or among the Fathers as to the meaning. [...] As a result geocentrism has become a "matter of faith" according to the principle of de dicto truth!

These are, indeed, remarkable synergetic dynamics, fuelled by authoritarianism, of two Church teachings that up to that point had not yet come together.

What of St. Augustine's principle to give up the literal sense of the Scripture as soon as it contradicts 'highly certain results of reasoning or empirical evidence'? Bellarmine does not contest this exegetic principle, and rightly responds that Copernicanism was far from being able to claim such an elevated epistemological status. Therefore, it is the word of the Scripture that counts.

Now we also understand why the Church in the condemnation of Copernicanism in 1616 (and later in 1633) could insist on judging this cosmological theory not only as 'formally heretical' and 'erroneous in faith' but also 'foolish and absurd in philosophy.' ${ }^{\text {6 }}$ Because Aristotelian natural philosophy is a kind of systematic presentation of everyday experience, it is to a large degree at least compatible with the respective cosmological ideas of the authors of the Scripture that also largely express everyday experience. Thus a special philosophical (scientific) view of nature is commanded by the Scripture, an idea so bizarre and so contingent on Bellarmine's authoritarian character that it comes as no surprise that it took seventy-three years to develop. ${ }^{67}$ Given these contingencies, it is, moreover, easily conceivable that the condemnation of Copernicanism may never have happened.

\section{Selective Bibliography}

Augustinus Aurelius, Über den Wortlaut der Genesis-De genesi ad litteram libri duodecim. Der große Genesiskommentar in zwölf Büchern, vol. 1., trans C.J. Perl (Paderborn: 1961).-The Latin text is available at: http://www.sant-agostino.it/ latino/genesi_lettera/index2.htm.

65 Blackwell, Galileo 105f.

66 'Philosophy' includes 'science,' cf. fn. 7.

67 Bellarmine's intellectual strength - he was at that time seventy-four - might also no longer have matched his institutional power in the Holy Office. 
Baldini U. - Spruit L. (eds.), Catholic Church and Modern Science: Documents From the Archives of the Roman Congregations of the Holy Office and the Index, vol. I (Sixteenth Century Documents) in 4 parts (Vatican City: 2009).

Barker P., "The Role of Religion in the Lutheran Response to Copernicus", in Osler M. (ed.), Rethinking the Scientific Revolution (Cambridge: 2000) 59-88.

Barker P. - Goldstein B.R., "Realism and Instrumentalism in Sixteenth Century Astronomy: A Reappraisal", Perspectives on Science 6 (1998) 232-258.

Blackwell R.J., Galileo, Bellarmine, and the Bible. Including a Translation of Foscarini's Letter on the Motion of the Earth (Notre Dame: 1991).

Carrier M., Nikolaus Kopernikus (Munich: 2001).

Constant E.A., "A Reinterpretation of the Fifth Lateran Council Decree Apostolici regiminis (1513)", Sixteenth Century Journal 33, 2 (2002) 353-378.

Copernicus Nicolaus, "On the Revolutions", trans. E. Rosen, in Dobrzycki J. (ed.), Complete Works, 3. vols. (London: 1978) vol. 2.

Copernicus Nicolaus, "Minor Works", trans. E. Rosen, ed. Czartoryski P. (ed.), Complete Works, 3. vols. (London: 1985) vol. 3 .

Copernicus Nicolaus, Gesamtausgabe, Nobis H.M. - Folkerts M. - Kirschner S. Kühne A. (eds.): Vol. II: De revolutionibus Libri Sex, Nobis H.M. - Sticker B. (eds.) (Hildesheim: 1984); Vol. vi.1: Documenta Copernicana - Briefe: Texte und Übersetzungen, Kühne A. et al. (eds.) (Berlin: 1994); Vol. vırı.x: Receptio Copernicana-Texte zur Aufnahme der Copernicanischen Theorie, Nobis H.M. Pastori A.M. (eds.) (Berlin: 2002).

Danielson D., The First Copernican: Georg Joachim Rheticus and the Rise oft he Copernican Revolution (New York: 2006).

Denzinger H. - Hünermann P. (eds.), Enchiridion Symbolorum definitionum et declarationum der rebus fidei et morum-Kompendium der Glaubensbekenntnisse und kirchlichen Lehrentscheidungen, 40th edn. (Freiburg: 2005).

Finocchiaro M.A., The Galileo Affair: A Documentary History (Berkeley: 1989).

Garin E., "Alle origini della polemica anticopernicana", Studia Copernicana 6 (1973) $31-42$.

Gingerich O., The Eye of Heaven: Ptolemy, Copernicus, Kepler (New York: 1993).

Gingerich O., An Annotated Census of Copernicus's De revolutionibus (Nuremberg, 1543 and Basel, 1566) (Leiden: 2002).

Gingerich O., The Book Nobody Read: Chasing the Revolutions of Nicolaus Copernicus (London: 2004).

Goddu A., Copernicus and the Aristotelian Tradition:Education, Reading, and Philosophy in Copernicus's Path to Heliocentrism (Leiden: 2010).

Goldstein B.R., "Copernicus and the Origin of His Heliocentric System", Journal of the History of Astronomy 33 (2002) 219-235. 
Hooykaas R., G.J. Rheticus' Treatise on Holy Scripture and the Motion of the Earth with translation, annotations, commentary and additional chapters on Ramus-Rheticus and the development of the problem before 1650 (Amsterdam: 1984).

Jedin H., "Katholische Reform und Gegenreform", in idem (ed.), Reformation: Katholische Reform und Gegenreformation (Freiburg: 1967) 449-604.

Kambartel F., Erfahrung und Struktur. Bausteine zu einer Kritik des Empirismus und Formalismus (Frankfurt a.M.: 1968).

Lerner M.-P., "L'hérésie' héliocentrique: du soupçon à la condamnation", in Sciences et religions. De Copernic à Galilée (1540-1610). Actes du colloque international organisée par l'Ècole française de Rome. En Collaboration Avec L'Ecole Nationale Des Chartes Et L'Istituto Italiano per Gli Studi Filosofici, Avec La Participation De L'Universita Di Napoli Federico II (Rome: 1999) 69-91.

Lerner M.-P., "Aux origins de la polémique anticopernicienne (I): L'Opusculum quartum de Giovanmaria Tolosani (1547-1548)", Revue des sciences philosophiques et théologiques 86, 4 (2002) 681-722.

Mayaud P.-N., La condamnation des livres Coperniciens et sa révocation à la lumière de documents inédits des Congrégations de l'Index et de l'inquisition (Rome: 1997).

Mayaud P.-N., Le Conflit entre l'astronomie nouvelle et l'Écriture Sainte aux XVI $I^{e}$ et XVII ${ }^{e}$ siècles. Un moment de l'histoire des idées autour de l'affaire Galilée, 6 vols. (Paris: 2005).

Prowe L., Nicolaus Copernicus, 2 vols. (Berlin: 1883/84; reprint, Osnabrück: 1967) vol. 1 in 2 parts.

Rosen E., Three Copernican Treatises: The Commentariolus of Copernicus; The Letter against Werner; The Narratio Prima of Rheticus (New York: 1939, 1971).

Stuhlmacher P., Vom Verstehen des Neuen Testaments. Eine Hermeneutik (Göttingen: 1979).

Swerdlow N.M., "The Derivation and First Draft of Copernicus'ss Planetary Theory: A Translation of the Commentariolus with Commentary", Proceedings of the American Philosophical Society 117 (1973) 423-512.

Swerdlow N.M. - Neugebauer O., Mathematical Astronomy in Copernicus's De revolutionibus, 2 vols. (New York: 1984).

Westman R.S., The Copernican Question: Prognostication, Skepticism, and Celestial Order (Berkeley: 2011).

Wolf H., Der Vatikan und die verbotenen Bücher (Munich: 2006). 